\title{
TV-SCHOOL HYBRID LITERACY PRACTICES AS SITES FOR MAKING ANOTHER LOGIC POSSIBLE: VOICING CONTRASTS THAT PROMOTE GENDER AND SEXUALITY TRANS-EXPERIENCES ${ }^{1}$
}

(Hibridismo TV-escola em práticas de letramento como lógica possível: contraste de vozes na produção de trans-experiências de gênero e sexualidade)

\author{
Branca Falabella Fabrício ${ }^{2}$ \\ (Federal University of Rio de Janeiro) \\ Luiz Paulo Moita-Lopes ${ }^{3}$ \\ (Federal University of Rio de Janeiro)
}

\begin{abstract}
RESUMO
Levando-se em consideração a relação entre mídia e processos de construção de sentido, o propósito deste artigo é examinar uma etnografia colaborativo-intervencionista realizada em um contexto de letramento específico - aulas de História em uma escola pública, nas quais a professora, dois pesquisadores e alunos de $5^{a}$ série do ensino fundamental trabalham cooperativamente no descentramento de visões naturalizadas de gênero e sexualidade. Fazendo amplo uso de textos midiáticos e de hibridismo radical, o grupo trabalha na construção de práticas de letramento que desestabilizem certezas, ao fazê-lo atravessar fronteiras (MIGNOLO, 2000) e negociar novas perspectivas para a vida social. Ao dramatizar vozes sociais cristalizadas e se engajar no que chamamos de trans-experiências, o grupo indica que matrizes sociais e significados solidificados, em lugar de simplesmente se imporem aos indivíduos, são reanimados e reconstruídos na interação. Tal movimento ganha visibilidade através da abordagem microanalítica empregada que, ao capturar contrastes sutis de vozes, indexicalizados por diferentes registros, explora um fluxo performativo robusto, apesar de quase imperceptível em sua delicadeza.
\end{abstract}

\begin{abstract}
Considering the relationship between media and sense-making in Brazil, the purpose of this article is to examine an interventionist collaborative ethnography in a specific literacy context - history classes in a Brazilian state school, in which the classroom teacher, two researchers, and $5^{\text {th }}$ grade students conjointly try to decenter commonsense views of gender and sexuality. By making ample recourse to media texts and to radical hybridity, they work towards promoting classroom literacy practices which "de-ground" certainties by shaking them through border-crossing (MIGNOLO, 2000) and triggering the negotiation of new perspectives for social life. By dramatizing cemented social voices and engaging in what we have termed trans-experiences, participants show that social matrices and solidified meanings do not simply impose themselves on individuals but live through microsociological encounters. This movement is made visible through a microanalytical approach that, capturing tenuous voicing contrasts indexed by register use, reveals a delicate, but significant, performative flux. Key words: hybrid literacy practices, voicing contrast, trans-experiences, gender and sexuality
\end{abstract}

\footnotetext{
${ }^{1}$ We are grateful to the Brazilian National Research Council (CNPq grants : 303301/2009-0 and 309246/20105) and to the Rio de Janeiro Research Foundation (FAPERJ grant: E -26/11 0.065/2021) for making the research reported on here possible.

2 Branca Falabella Fabrício, Associate Professor in Applied Linguistics, Department of Modern Languages, Interdisciplinary Graduate Studies Program in Applied Linguistics, Federal University of Rio de Janeiro, Av. Horácio Macedo, 2151 - CEP 21941-917, Cidade Universitária, Rio de Janeiro - RJ, Brazil, Room F317. E-mail: brancaff@globo.com

3 Luiz Paulo da Moita-Lopes, Full Professor in Applied Linguistics, Department of Modern Languages, Interdisciplinary Graduate Studies Program in Applied Linguistics, Av. Horácio Macedo, 2151 - CEP 21941917, Cidade Universitária, Rio de Janeiro - RJ, Brazil, Room F317. E-mail: moitalopes@ oi.com.br
} 
"the appeal of hybridity as a framing device must be seen as a strategic one .... That is, the presentation of objects as culturally mixed, as creolized or hybrid forms, is valuable for its contradiction of an essentialized order" (THOMAS, 2000, p. 199)

"Whenever two colors are bound to be mixed or joined, a third one bursts in between them " (GRUZINSKI, 1999, p. 50)

\section{HYBRID LITERACY PRACTICES AND MEANING-MAKING}

In the so-called New Media Age, media texts have been playing a central role in the construction of new meanings about social life and its actors. Of all mass media modes, television undoubtedly presents a significant part of the intertexts people resort to in their everyday interactions in the workplace, at school and at home, since the rapid, and ceaseless, profusion of visual images came to participate in the construction of our worldviews, lifeworlds and overall experiences. In Brazil, the centrality of television is undeniable if compared with other countries where the radio and the written press are, at least, as crucial as the TV. Its appeal and power are so intense that the world shown on TV and the country's daily life blend into an everyday hybrid screen-life - a mechanism affecting on-going identity construction processes.

Taking into account this inextricability concerning media and sense-making, this article examines an interventionist collaborative ethnographic classroom research project in a specific literacy context - history classes in a Brazilian state school, in which both the classroom teacher and one of the researchers, working with $5^{\text {th }}$ grade students, conjointly try to destabilize commonsense views of gender and sexuality. By making ample recourse to media texts and to radical hybridity, they work towards promoting classroom literacy practices which "de-ground" certainties by shaking them through border-crossing (Mignolo 2000) and triggering the negotiation of new perspectives for social life. We believe that a concern with radical hybridity in literacy contexts offers such a "de-grounding".

In order to support this claim, we start by focusing on the role TV literacies play in contemporary society at large and in the present educational scenario in particular. We then provide theoretical justification for the need of re-describing social life in view of a myriad of contemporary meanings which have de-traditionalized or questioned social life and which have hybridized it, requiring constant border crossing. This section is inspired by Mignolo's borderland theory. We proceed by introducing a theoretical view of gender and sexuality as performance, which is informed by queer theorists such as Butler (1990). We then put 
forward the research context, the research methodology and a discourse micro-analytical framework which can capture how inter-discursive meanings and voicing contrasts (Agha 2005) -- a result of hybridizing school and TV discourses in schools -- may 1) generate what we have termed trans-experiences; and 2) as a corollary, collaborate with the reconfiguration of crystallized meanings about gender and sexuality performances. After centering on the analysis of classroom interaction, with a view to drawing attention to how novel meaningexperiences and border-crossing are brought about, we conclude by discussing some of the implications of the hybrid directions suggested. Questions that we explore in the study include: What counts as literacy and learning in school settings? What opportunities for voicing are created in classrooms? Whose voice gets foregrounded? What kind of meaning experiences does classroom talk promote?

\section{TV LITERACIES IN BRAZIL}

There are two main theoretical stances underlying our study. The first involves theorizing TV meaning engagement as a literacy social practice; the second, perhaps a less commonly taken perspective, relates to considering the educational use that can be made of such a literacy practice to reinvent discourses about gender and sexuality.

In a world in which the sources of meaning construction are no longer restricted to the written word, the relevance of the electronic media as a crucial type of contemporary literacy has become a truism. We have moved from a world of literacy to a world of multiliteracies (COPE; KALANTZIS 2000a), in which written word literacy is referred to as "mere literacy" (COPE; KALANTZIZ 2000a, p. 5). As a corollary of having left a monomodal world and being immersed in a multimodal world of meaning construction (Kress 2003), life nowadays is more and more lived in front of TV, computer and cell phone screens. We are required to handle hybrid ways of constructing meanings, in which images, words, voices, music, design etc. are simultaneously resorted to. Still more importantly, because of the diverse globalized discourses which are typical of the electronic media (even of the open TV channels), everyday life has become more and more glocalized (ROBERTSON, 1995), often as a result of the hybridization of discourses.

Nevertheless, despite the centrality of TV in the articulation of meanings which guide contemporary life, it is rare that interaction with televisual texts is considered a relevant source of meaning construction in the educational context and therefore as a kind of literacy. This is particularly so in Latin America, as the Colombia-based Spanish media theorist Martín-Barbero (2001, p. 25) points out: "intellectuals and the social sciences are insensitive 
to the cultural challenges that the media present, in particular as regards the TV'. In the field of literacies in Applied Linguistics, it is not less so: TV literacies have seldom been considered as a site for education by teachers and researchers in Brazil.

As we have actually heard from a Brazilian literature professor: "there is already so much television in society, why bother about it at school?" Such an argument underlies her view for the necessity of emphasizing the teaching of literature texts in schools. While we do not disagree that there is an educational need for learning to read literary texts (as well as other genres), it is exactly this ubiquity of TV in Brazilian society which prompts us to explore it as a potential literacy practice with a view to drawing attention to hybridized meanings and simultaneously to the performative nature of meaning, in particular about gender and sexuality. We take the view that this position may inaugurate another logic in schools with the hope that it may contradict traditional perspectives of gender and sexuality existing in society.

Educated at universities, which still favor written language above all, teachers equally consider the written word (the classics in literature and in their fields) as their only concern. Schools are about the so-called learned cultures and not about popular cultures. Nevertheless, the world of television and its discourses are constantly resorted to by pupils to make sense of whatever goes on in classrooms (MOITA-LOPES, 2005) and by teachers themselves (as by everybody else) outside classrooms in Brazil. It is our contention that TV literacies are an important source of learning: both as a way of validating students' meanings/ interdiscourses about whatever texts they are involved with in classrooms (including literary texts) and as a way of exploring the hybrid nature of contemporary cultural life in which, among others, the worlds of learned cultures and of popular cultures intersect.

In other fields of research, in communication and cultural studies, for example, the centrality of TV in Brazil has, however, been crucially emphasized. It has been said that, in Brazil, TV screens and life often blend into one single entity, constructing a hybrid reality (BUCCI, 2004, p. 226) in a world in which what really matters is the image (BUCCI; KEHL, 2004). The word and the printed word have been fluidized due to the status of the images over words, a process Canclini (1997) has referred to as "the empire of the icon". Therefore, it comes as no surprise that, as Bucci (2004, p. 222) puts it, "TV is the medium which identifies Brazil for Brazilians themselves" or "if we remove TV from Brazil, Brazil disappears" (p. $31)$. 
It is thus paramount that we consider TV literacies as important sites in which meanings about social life and knowledge are constructed. In a country in which most houses have a TV set (TRAVANCAS, 2007), TV literacies face no competition from other kinds of literacies, including computer literacies, if the relative limited number of computer access in Brazil is taken into account. In fact, TV literacies are the only kind of literacy which cuts across society from top to bottom - independently from age group - whereas computer, books, newspapers, magazines and the literacies they entail are mostly restricted to the middle and upper classes ${ }^{4}$.

In this connection, it should be added that Brazil is the seventh world TV producer (CANCLINI, 1989; 2000). Despite the existence of other national open TV networks, the uniqueness of a particular TV network - Globo TV - in Brazil has to be emphasized because of its ubiquity in many Brazilian homes. Specifically, the 8:30 National News and the 9 o'clock soap-opera shows - watched by millions of spectators (encompassing adults, teenagers and even children) - are the sources of conversation topics for most social sectors and social classes. As the leading TV network, what is shown on Globo TV is both a view of what happens in society and, at the same time, what society, in general, reflects upon. As a popular motto repeated by Globo TV presenters goes: "Brazilians meet on this TV channel". It is surely a crucial literacy practice in the country.

The picture drawn above implies that TV has virtually substituted for the public sphere in Brazil, since it is the great mediator of contemporary life: participation in public life has to do with "an audiovisual democracy" (CANCLINI, 1997; 2000 p. 290). It is on the TV screens that many of the meanings of contemporary life are decided upon, fought over or negotiated. This fact does not imply that there is a single flux of meaning going from TV screens to viewers. TV discourses are part of everyday conversation and there is no way to predict what TV audiences do with the meanings they are exposed to on TV screens. As Sarlo (2000, p. 67) says: "as a democratic and public mirror, as a mirror of the totality of the audience, [...] TV constitutes its referents as audiences and its audiences as referents". TV discourses may be seen as a reflection of what is already in the streets, but their circulation on TV screens increases the reflexivity about such discourses. They may have effects on the audience and may collaborate with the construction of the meanings with which the audience operates or with their re-construction. It comes as no surprise, therefore, that they are crucial in

\footnotetext{
${ }^{4}$ It is true however that access to computer literacies in Lan Houses in the periphery are helping to disseminate this type
} of literacy in Brazil (Moita-Lopes, 2010). 
contemporary social life in Brazil and that recourse to them in schools may help to understand what goes on in society and to inaugurate new social meanings, i.e., such meanings should be focused on in schools for one reason or another.

In addition, the appeal to the hybrid nature of contemporary life that the use of TV discourses in classrooms makes possible, as above mentioned, bringing about crossings between popular and learned cultures, for example, is also typical of whatever goes on TV not only because of the multiplicity of discourses which in a minute may go through the screen but also because of the multimodal semiotic means (images, words, music etc.), which construct such discourses. We argue that investment in such hybridity, coupled with innovative hybrid interactional strategies (temporal, spatial and attention/visual) in classrooms, may offer the possibility of de-essentializing social life by situating classroom meanings on the borderland (MIGNOLO, 2000) that hybridity makes possible. In accordance with Canclini (1997, p. 307), "we believe that irreverent crossings [in the borderland] are moments in which we can relativize fundamentalisms" of whatever persuasion.

The underlying argument is that such hybridity is instrumental in showing the performative and constructed nature of social life and, as such, may collaborate with the disruption of an essentialized order (THOMAS, 2000) and with the inauguration of alternative meanings. Such an order has traditionally oriented the construction of social identities and it has been paramount in defining the legitimate gender, sexuality, race, religion etc., i.e. fundamentalist ideals. Our ultimate concern is with the production of other discourses about who we can be or become, and with the possibility of reinventing social life. We are interested in helping to produce "a narrative that changes the present" (VENN, 2000, p. 2) or, perhaps, in putting forward alternatives to the present which question discourses legislating on what kinds of lives are possible. We understand that meanings about gender and sexuality (as well as others) have traditionally constituted an essentialist core, which needs to be degrounded in schools to contribute to social justice: much harm has been done to human-beings because of fundamentalist comprehensions of what men and women are like.

We rely on a view of literacy as situated social practice in which participants coconstruct textual meanings and, by so doing, construct /reconstruct meanings about social life and about themselves (GEE, 1994). Within this perspective, texts, and TV texts for that matter, do not have intrinsic meanings. Meanings are constructed by viewers as they get engaged with TV texts in a particular social practice. In different social practices with the 
same or different participants, texts are likely to have different meanings. We take it that literacy can be seen as a site in which participants are involved with contextualizing and recontextualizing social meanings (COPE; KALANTZIZ, 2000a, p. 7). As these processes tend to become more and more intense - the result, in fact, of the increase in text circulation -, the hybrid nature of discourse practices, though long overlooked, becomes more prominent.

\section{HYBRIDITY AND BORDERLAND THEORY}

Despite the relative recent concern with hybridity as a theoretical concept in the Social Sciences (Canclini 1989/2000; Gruzinski 1999; Brah; Coombes 2000), hybridity has singled out human life from immemorial times since when the first tribes contacted / fought others and exchanges / imposition of languages, ways of living, values, literacies and so on took place. Such practices brought about new ways of speaking, thinking, and being, not to mention biological hybridization. Latin America as a land of colonialism, whose marks are still noticed, can be seen as a land of pastiche and bricolage (CANCLINI, 1989; 2000), of the mestizo thought (GRUZINSKI, 1999) or of hybridization (CANCLINI, n/d). Despite the fact that Occidentalism may be seen as a process of legitimating as right whatever came from Europe (languages, race, ways of constructing gender and sexuality, religion etc.), with the consequential brutal human suffering it entailed (VENN, 2000), it inevitably led into mestizaje and hybridized ways of producing languages, lives, thoughts etc. Nevertheless, for ethnocentric reasons history rarely looked deeply into the mixtures with the non-occidental world (GRUZINSKI, 1999). However, as we have mentioned above, it is the space of hybridity, mestizaje and mixture which is of interest to us exactly because it produces novelty or novel discourses, a crucial theoretical-pedagogical device used in the literacy context studied in this paper.

This approach is contrary to traditional dualistic or binary ways of thinking which operate with clear-cut simplistic categories and as such go hand in hand with the occidentalist universalist epistemological search for purity, certainty and true knowledge (GRUZINSKI, 1999). However, if this type of logic was not operable to understand the colonized world, it is much less suitable to make sense of post-colonial times characterized by intense hypersemiotization in a highly mobile world in which texts, objects and people are moving through both cybernetic and physical porous frontiers (Appadurai 1996) - as social phenomena are increasingly questioning tradition. In such a world, oriented by a postoccidental order, the metaphor of hybridization seems to be more adequate to explain our lives as located in the borderland. As Mignolo (2000, p. ix) points out, "yesterday the colonial 
difference was out there, away from the center. Today it is all over in the peripheries of the centers and in the centers of the periphery". Also, we claim that, epistemologically, the gains of placing ourselves within this border-thinking logic are greater. If for no other reason, it has the potential for making us operate in a non-essentializing perspective, defying binarisms and escaping the limitations of fundamentalisms and well-defined categories, which jeopardize the variability of human experiences.

Border thinking is therefore conflictive with the concepts of the territorial limits of the nation-state and with the ideal of national languages, both being enunciations which derive from an occidentalist logic of colonial power exercise over conquered lands or subaltern knowledges (MIGNOLO, 2000). Border thinking thrives on abandoning "the rigidity of epistemic and territorial frontiers" (p. 12), which is in line with "indisciplinary" forms of knowledge production (MOITA LOPES, 2006; 2011) and with a porous world. Such a perspective opens up possibilities for ascribing prestige to local histories, "unimportant" experiences, popular knowledges and hybridization of discourses, worldviews etc. in the borderland (MIGNOLO, 2000). Differently from colonial times, the borderland is the place "of a desired epistemological potential" (p. 29), "of another thinking" (p.69), or "of another $\operatorname{logic} "($ p. 70).

\section{GENDER AND SEXUALITY AS PERFORMANCE: A QUEER THEORY PERSPECTIVE}

Although theorizing gender and sexuality from a poststructuralist perspective, like borderland theory, queer theory is also critical of binarisms, in particular of the gender and sexuality binaries - male / female and heterosexuality / homosexuality - which still inform contemporary commonsense views. From a different perspective, queer theory operates within the same ideal of establishing another logic or another thinking: equally a deessentializing view, in this case, of gender and sexuality.

It particularly derives from the work of Judith Butler (1990, 2004, for example) which, mainly inspired by Austin, Foucault and Derrida, draws attention to the discursive performative nature of gender and sexuality. She argues that they are performative in the sense that they are constituted by acts which are socioculturally interpreted as masculine/feminine or heterosexual/homosexual. These performances do not exist before discourse or before their doing. It is then the doing which constitutes the subject: he or she is not the cause of such doing. Such acts are continually repeated within certain sociocultural rules to the point that at the same time that they describe / refer to what they are in the doing, 
they produce meaning effects or an appearance of substance to what is done here and now in discourse. It is then the performance which produces who we are, i.e., our performances are not the essence of who we are. Such acts are performative since they constitute, on the basis of corporeal-discoursal maneuvers, a sense of essence to what is in fact fiction.

Such theorizing of gender and sexuality as performance made possible ways of understanding performance as masks one can put on at one's will. Nevertheless, it is our view that this kind of approach does not make sense since performances are not ready-made artifacts / meanings one can make recourse to; rather they are intersubjective actions dependent on repeated and sedimented meanings which, once projected by an interlocutor, have to be ratified (or not) by an audience. Not acknowledging this dialogical process erases the performative nature of gender and sexuality. Therefore, to avoid such a pitfall, we follow Pennycook (2007) and subscribe to the distinction between the notions of performative and performativity: on the one hand, the performative accounts for given existing meanings and, on the other, performativity allows for the creation of new meanings about identity and social life possibilities since performances are never the same. Also, because they are performed for and to others, they depend on the meanings constructed by others (Sullivan 2003; Coupland; Garrett; Williams 2005).

Considering this view, we should avoid the comprehension of performance as allowing for whatever choices one can make about whom one wants to become, since we have to account for one's performances meaning-effects here and now. Nevertheless, we should equally refuse the view that we can only get involved with hypercrystallized performances, which have been previously prescribed. This is an important point because it opens up the possibility of transgressing calcified meanings and operating within another logic: a crucial concern in this study.

The de-essentialized view of gender and sexuality as performances have been appropriated by queer theorists, who place sexuality beyond the homosexuality and heterosexuality binary, taking into account a more encompassing category: queer. In queer theorizing, gender and sexuality are considered as always in construction, in a continual becoming (JAGOSE, 1996, p. 131), or in transition. Queer, as a theoretical construct, problematizes any transcultural, transhistorical and universalist view of genders and sexualities, taken to be "a constellation of multiple and unstable positions" (JAGOSE, 1996, p. 3). The logic which underlies queer theory is thus the logic of uncertainty, instability and hybridity, a conceptualization radically distant from the heteronormative matrix (BUTLER, 1990, p. 136) which has historically informed commonsense views of gender and sexuality. 
Therefore, a queer perspective de-naturalizes both heteronormativity and homonomartivity, considering the "all-encompassing" binary homo-hetero as inappropriate to account for the fluid nature of sexuality and its several performances.

\section{RESEARCH CONTEXT, METHODOLOGY AND ANALYTICAL FRAMEWORK}

Our data were generated, in 2005, in a Brazilian state school located in a highly populated urban center in Rio de Janeiro, offering all levels of instruction, from kindergarten, to primary and secondary schooling. The institution congregates teachers and pupils (about 2,000), mixing middle-class, lower middle-class and working-class students and professionals.

One of the school's history teachers accepted to take part in our research on classroom (de)construction of genders and sexualities. She helped us negotiate, and obtain, the permission of the school principal to carry out the investigation, which, besides drawing on video and audio recordings, field notes and interviews made along a one-year ethnography, involved multiple forms of cooperation between the teacher and researchers: 1) the collaborative design of teaching materials (handouts and discussion sheets) by making recourse to media texts and images on genders and sexualities; 2) decisions on pedagogical procedures and methodology; 3) the observation, by one of us, of a specific group of $5^{\text {th }}$ graders (encompassing 17 girls and 13 boys around 10-11 years of age) throughout one school year; 4) the engagement in cooperative team-teaching (as the teacher and the observer agreed to switch roles whenever emerging contexts required so); and, 5) attendance at staff meetings. This conjoint action also involved reflective sessions in between classes to analyze the work just done and to organize the following classes.

The teacher welcomed this research design for different reasons. On the one hand, she was having difficulty in handling racist and homophobic manifestations in her classes. On the other, although she felt that these issues had to be overtly addressed in class through the enhancement of group discussions and reflective thinking, she felt frustrated at the disorganized and loud way students acted on those occasions. Moreover, she had long felt the recurrence of talk about gender and sexuality in her classes generated by students' constant recourse to their blended TV repertoire and social experiences to make sense of official curricular topics.

In order to address this educational environment, we developed a program that made room for students to bring in their experiences and to have a more preponderant voice during 
classes, articulating classroom life and students' lived trajectories in their communities and exploring their textual repertoire (deriving mainly from TV, popular newspapers, magazines and comic strips). We started out with gender and sexuality, the most recurrent topics on students' discourses, approaching them as complex intersubjective sociocultural performative phenomena rather than as biological conditions. By putting gender and sexuality issues at the front of the educational agenda, we expected to shake both the gender divide and the heteronormative matrix which play crucial roles in the ways we historically learn to 1) understand the self and others and 2) construct patterns of normalcy and deviance. As we have stated elsewhere (cf. FABRÍCIO and MOITA LOPES 2010), starting an educational project involving deconstruction by questioning what is believed to be the core of our identity (i.e. gender and sexuality) may open the way to the disturbance of other socioculturally solidified beliefs about who we are and can be.

We also invested in radical hybridity coupled with innovative hybrid interactional strategies (temporal, spatial and attention/visual) in classrooms, as a strategy offering the possibility of de-essentializing social life by situating classroom meanings on the margins / borders that hybridity makes possible. The proposed hybrid curriculum included:

- working with a range of genres and multimodal texts;

- employing a talk-about-text approach (MAYBIN; MOSS 1993), to tackle challenging and frequently silenced topics in the official curriculum (race, ethnicity, gender and sexuality, for example) through a non-essentialist perspective;

- encouraging students to develop an ethnographic stance toward sociocultural life, by involving them in recurrent research activities in their own community (EGANROBERTSON; BLOOM, 1998);

- comparing texts, engaging youngsters in a reflective process concerning the consequences of our discourse actions;

- questioning dominant ideologies concerning identities and alterities by exposing students to varied possibilities of being;

- carrying out varied activities enhancing critical and border thinking, capitalizing on discussions about genders and sexualities;

- developing multiple ways of sharing the negotiation of power and control with students;

- promoting diverse spatial arrangements and participation structure;

- enhancing varied institutional performances other than "teacher" and "student";

- encouraging students to imagine alternative ways of being in the world. 
The purpose of these transformative practices was to frame the classes as a hybrid and constantly changing landscape where standardized institutional rules and social life dynamism merge ${ }^{5}$ and where border-thinking may come into existence. It is within this non-fixity frame, which promotes mixing in general (at the expense of cemented discourses) and foregrounds students' voices and hybrid contemporary texts, that different self and intersubjective experiences can be engendered. Therefore, hybridity was employed as a strategy and as a necessary structural, pedagogical and methodological modus operandi rather than gratuitous eclecticism: a strategy for friction, deconstruction and relocation.

To make this concept of hybridity operational, we relied on a view of culture as hybrid, "dynamic, open and, and forever undergoing transformation (...) an account of culture which has implications for individual responsibility and the ethics of participation (COPE; KALANTZIZ, 2000b, p. 205). If our discourse experiences act upon the sociocultural world, always recreating it afresh, it is thus essential that we pay attention to the consequences of our actions, becoming more active and responsible social actors.

The study has generated a great amount of ethnographic data but for the purposes of this paper we have concentrated on the material ${ }^{6}$ related to eight consecutive classes ${ }^{7}$ which may illustrate how this curricular perspective offered guidelines for dealing with gender and sexuality performances. In what follows we discuss the intersubjective meaning-effects of its implementation, by focusing on a single classroom scene - part of a specific class (cf. Appendix, class 5). We approach it through the observation of patterns of register use, the voicing effects they project and the forms of alignment they establish. Within this analytical focus, we follow Agha's articulation of the notion of register with the Bakhtinian (Bakhtin 1981) and Goffmanian (Goffman 1981, 1974) conceptions of voice and alignment, respectively (cf. Agha 2005). In the author's perspective, these three concepts signal pragmatic features of interpersonal relationship - an approach which focuses on how interlocutors project themselves vis-à-vis one another in emergent contexts, establishing a dialogue which occurs in both the local interactional and the larger social orders.

Register use, through sociohistorical patterns of repetition, comes to be recognized as indexing stereotypic speaking personae and social attributes such as gender, age, class, etc.,

\footnotetext{
${ }^{5}$ A more thorough discussion on how contexts are always in motion, comprising both perduring and emergent meanings, which cohabit in a state of constant friction, can be found in Pennycook (2010) and Fabrício (2012).

6 The material regarding these eight classes encompasses a total of 16 hours of observation and has been translated from Portuguese into English.

${ }^{7}$ Four of these classes (4-7) are discriminated in the Appendix for the sake of exemplification.
} 
i.e. typifiable social voices. The typifiability of voices, Agha argues, presupposes voicing contrasts dialogism and reflexivity in two interlaced, but different, ways. Firstly, the juxtaposition "of images of speaker-actor as contrasting with or appearing to react against each other" (p. 39) allows for the differentiability of one voice from another - a process also involving specific linguistic and paralinguistic signs (pitch and intonation, for example) and other nonlinguistic semiotic activity (such as body language, body spacing, facial expression and gestures) which index a range of pragmatic values associated with their forms, in the social domain of language users who are familiar with these forms and values. Secondly, registers in use, in specific communicative events, besides indexing identifiable sociocultural figures through contrasting voices, establish, at the local level, relationships and alignments toward interlocutors (speaker and audience) and toward the very same performed / projected figures. That is to say that the kind of dialogue at play is not confined to a single interactional encounter, as small-scale phenomena of language always re-enact wider sociohistorical semiotic practices.

These analytical lenses helped us produce intelligibility concerning hybridized meaning-making in the classroom. As participants got engaged in the operationalization of the designed hybrid syllabus, to which we now turn, the approach enabled us to detect the way young interlocutors weave together popular culture and school culture and the performatity effects that such liaison foment.

\section{HYBRID CLASSROOM PRACTICES: AN EXAMPLE}

The data in the classroom scene below, generated in the third school term, occurred after students had been long familiar with the above mentioned pedagogical procedures and with the presence of the researcher in class. It was selected because besides synthesizing recurrent discursive actions in our corpus it enabled us to highlight 1) the intertextual chains TV texts enter into; 2) the hybrid literacy practices at play, the performances they precipitate and their performative force; and, 3) the relationship between micro-level communicative events and the wider social realm, a process related to prospects of transformation and to the design and "refashioning" of social futures (Pennycook 2007; Cope; Kalantzis 2000a). Therefore, we have favored moments of mobility, flow and ambulation, which could have easily been by-passed had we not examined participants' (students', the teacher's and the researcher's) capillary movements.

The excerpt shows how they work conjointly during a task-presentation activity on gender stereotypes (cf. Appendix, class 5). After having done research on essentialized 
cultural ideas concerning male-female dualism, which included looking for media images depicting stereotypical portraitures of men and women, pupils - in groups of three, standing before the whole class and addressing it as a group - take turns sharing their tasks with interlocutors. The latter, sitting in rows, support task-presenters by keeping eye-contact, nodding, making comments and asking questions. The teacher, mingled with students, occupies a desk in one of the final rows, while the researcher, managing the camcorder, stands behind the video camera placed on a tripod in the right corner of the room.

\begin{tabular}{|c|c|c|}
\hline & & $\begin{array}{l}\text { ((standing in front of the group, and keeping eye contact with it, referring to the research } \\
\text { work carried out at home; class also keeps eye contact)) }\end{array}$ \\
\hline 01 & Bete: & I've researched about the boys, here ... and I wrote that in society all boys have to be \\
\hline 02 & & rebels, can't have anything organized, they have to have like ... they don't need to \\
\hline 03 & & study, otherwise he is that kind of limp wristed person you know? So, here it's saying \\
\hline 04 & & that all boys have to have rock bands and their rooms have to be full of $[\ldots$ \\
\hline 05 & Some students: & $\begin{array}{l}\text { [graffiti } \\
\end{array}$ \\
\hline 06 & & with those skulls, like, totally rebellious, $\frac{\text { completely rebellious and also, there's stuff }}{[((\text { stereotyped intonational pattern }))}$ \\
\hline 07 & & about girls, that every girl has to be like [a little doll, and in her room she has to have \\
\hline 08 & & those pink little cushions with little animal ornaments, that pen with fluffy pompons, \\
\hline 09 & & uh::: she has to wear little skirts, full of little things [... little hearts, little stars, little \\
\hline 10 & Jorge: & [little hearts \\
\hline 11 & & clouds. She has to be over the phone with her girlfriend for one hour ... and I also have \\
\hline 12 & & stuff about the men. Society says that men don't have to be hairdressers, because this is \\
\hline 13 & & a woman's job, and that a man that does it, he is like, he becomes a faggot if he is a \\
\hline 14 & & hairdresser, because this, you know, by no means is men's stuff. Because men have to \\
\hline 15 & & be businessmen, or stuff like this. \\
\hline 16 & Researcher: & Bete, where have you found this information? \\
\hline 17 & Bete: & Oh, I've found some of them in the Channel. \\
\hline 18 & Researcher: & Channel Magazine? \\
\hline 19 & Bete: & Yeah, and here it talks about women, they can't, a woman can't play like this, I mean, \\
\hline 20 & & she can but it's a little strange if she appears on TV playing soccer, doing sports, \\
\hline 21 & & parachuting, otherwise people will call her a dyke because doing things like that, \\
\hline 22 & & although TV shows it, women playing beach soccer and stuff but it's kind of weird, isn't \\
\hline 23 & & it? Society says it's completely weird, because soccer is men's stuff, this is what society \\
\hline 24 & & says. That's all. \\
\hline
\end{tabular}

Classroom Scene ${ }^{8}$

Grade: $5^{\text {th }}$ grade

Number of students: 32

Age group: 10-11 year olds

Activity: task presentation (in groups of three)

Theme: gender stereotypes

Spatial configuration: task presenters stand before audience

In order to understand the meaning-making process students are involved with, we have to resort to the TV intertexts intertwined with Bete's discourse and students' literacy

\footnotetext{
${ }^{8}$ For transcription purposes we have used the following notation: " $(())$ " identifies comments on non-linguistic behavior and/or clarification; underlined words stand for emphasis; “...” indicates quick pause; and "[" signals overlapping talk and/or semiotic actions. The pupils' names (Bete and Jorge) are fictional.
} 
(televisual and reading) experiences, a situation which throws light in the aforementioned hybrid screen-life. When the above interaction took place a popular soap-opera was being aired ${ }^{9}$ which presented two contrasting characters: an independent masculine-looking teenage girl and her cousin, the stereotypical blond clueless doll. The former played soccer with the boys in the neighborhood, being criticized by her aunts and cousin. The latter, a fortune hunter, managed to marry a rich guy. Moreover, another soap-opera show - a big hit aired in $2004^{10}$ - was still fresh in students' memory, specially the main characters constituted by a domineering mother who coached her four sons for martial arts championships. Three of them submitted to her and performed "radical" maleness, i.e., rudeness, muscular strength, rough voice quality and brutish ignorance; the youngest one, however, wanted to become a hairdresser, only taking interest in beauty treatments; he was mocked, criticized and discriminated against by the rest of the family. These programs - containing a plentiful display of gender and sexuality performance possibilities, in which characterization tends to typification - and news published in Channel Magazine - a weekly Sunday supplement of a popular Brazilian tabloid covering TV shows - provided part of the script students resort to in reflecting upon naturalized constructions of gender.

In Bete's presentation (cf. lines 1-24), for example, it is clear how the soap-opera characters helped her and some classmates, in a complementary duet (cf. lines 5 and 10), to provide a reflecive portraiture of the social rules guiding gender performance, which signal a queer understanding of a social heteronormativity matrix, i.e. the young girl is able to distance herself from familiar flattened patterns tending to typification (a characteristic of many popular TV texts), by making them strange. This activity is subtle, though, and involves a complex structural architecture which could have escaped our attention without the use of the adopted microscopic scrutiny procedures. Different aspects of the student's discourse practice contribute to this idea.

Firstly, Bete displays awareness of gendered rules through her recurrent employment of deontic modality, by using an abundance of modals signaling obligation, prohibition and necessity as in "they have to be rebels" (lines 1-2), "they can't have anything organized" (line 2), they "don't need to study" (lines 2-3), "they have to have rock bands" (line 4), "every girl

\footnotetext{
9 "I heard it through the moon" ("A lua me disse") was produced by Globo TV and aired from April through October 2005.

10 "The color of sin" ("Da cor do pecado") was also produced by by Globo TV and aired from January through August 2004.
} 
has to be like a little doll" (line 7), "a woman can't play like this" (line 19) etc. Secondly, these linguistic cues project a critical ideological alignment concerning femininity and masculinity which is emphasized by the youngster's understanding that ideologies of gender are cross-cut by ideologies of sexuality, as indicated in "otherwise he is that kind of limp wristed person you know?" (line 3) and people will call her a dyke" (line 21).

This critical stance is intensified by a sophisticated process of voicing construal producing both contrastive individuation and, as a consequence, social characterization (Agha, 2005). By introducing her presentation with the statements "I've researched about ..." and "I wrote that in society ..." (cf. line 1), Bete projects two focal speakers, the "I" she invokes and "society", whose ideas she, as a researcher, "reproduces". The former is an analytical and reflective voice, whereas the latter is stereotypical and clichéd. It is their friction within a literacy practice that constructs a critical ideological position regarding gender identity kits. This voice is enacted by her use of registers associated with manhood and femaleness.

Concerning masculinity, the student projects a social identity linked to the image of "the chest-beating gorilla" by making recourse to different indexically loaded lexical elements - mainly adjectives and adverbs. The emphatic repetition in "totally rebellious" and “completely rebellious" (line 6) are gender markings that indicate wider ideological relations and histories. By the same token, femininity is indexed by the use of a register associated with females according to commonplace perceptions. Bete's appeal to a stereotyped intonational pattern and to diminutives and descriptive language creating a repetitive rhythmic effect in lines 7-11 ("little doll", "pink little cushions with little animal ornaments", "that pen with fluffy pompons", "she has to wear little skirts, full of little things ... little hearts, little stars, little clouds"), suggest a feminine figure linked to ideas of superficiality, futility, vanity etc. In Portuguese, such a semantic effect is achieved by the repetition of the structure "noun + suffix - inha/o" $" 11$, which aggregates ironical overtones to the discursive action, as it morphologically indicates diminutives, a use typically associated with feminine language in common sense.

By using such gender markings, Bete's performance recycles circulating discourses related to gender differences (boys are rebels, disorganized, have rock bands, like skulls and dislike studying; and girls are like Barbie dolls) and dichotomous constructions such as

\footnotetext{
${ }^{11}$ In Portuguese, lines 7-11 read like this (the repetinion of the suffix is highlighted in bold): “Toda menina tem que andar com uma bonequinha, e no quarto ela tem que ter aquela almofadinha rosa de bichinho, aquela caneta peludinha (...) tem que usar aquela sainha, toda com coisinha ... coraçãozinho, estrelinha, nuvenzinha (...)”
} 
"men's stuff" - like soccer, sports, parachuting, business - and women's stuff - having an interest in hairdressing and beauty treatments, being picky about clothes and accessories, chatting over the phone (lines 11-21). However, her semiotic actions are not sheer replication as the girl engages in border- crossing: she mixes local TV histories, "inferior" knowledges and school knowledge, concomitantly constructing a well-bounded territory (her stereotypical gender performance) and border questioning (her critical stance). Put it differently, she performs identification and dis-identification at the same time - a mobile and fluent experience, a trans-experience. Out of these juxtaposed actions, another logic was engendered with a disruption potential: that of reflexivity and critical thinking.

It is the performativity of the voicing contrast at play that signals that the student does not identify or align with the typified figures and social voices being projected. On the contrary, her position is critical-ironical, and in this sense, queer: aware of both the orienting heteronormativity matrix and, most importantly, the effects of "rule-breaking behavior", as expressed in "Society says it's completely weird" (line 23). This position - which illustrates a possibility of having youngsters engage reflectively in border-thinking - is ratified by the whole group whose members, through complementary moves (lines 5 and 10), such as gaze, eye-contact and listenership (signs of engagement), support the reflexive in-progress questioning activity concerning social binaries and frontiers.

\section{SOME FURTHER CONSIDERATIONS}

As participants in an interventionist collaborative ethnographic research project carried out in an educational institution, the researchers, the teacher and the students involved in it are concerned with the creation of atypical meanings about social life in school literacy contexts by making recourse to strategies with potential to problematize essentialized approaches to gender and sexualities. These strategies, relying on radical hybridity, mix media texts (mainly televisual ones), official pedagogical content, students' local voices and their literacy experiences. In the focused classroom scene, they have led interlocutors to the production of intertwined "stories", whose epistemology, deriving from original amalgams and performances, increase reflexivity, authorship and self-expression - indubitably fertile and beneficial learning practices.

Through the dramatization of cemented social voices, a student and her audience have shown that social matrices and solidified meanings do not simply impose themselves on individuals but live through microsociological encounters (of the kind reported on here), in which they are recontextualized in processes of reproduction, challenge or transformation. 
The micro-analytical path pursued - which threw light on tenuous voicing contrasts indexed by register use - was revealing of a delicate, but significant, performative flux. This movement has to do with both the collectively-produced conversational context and participants' ability to negotiate critical positions which may be consequential from the point of view of the displacement of crystallized perceptions of social life. In so doing they have defied gender binaries and borders, by producing voice friction between reproduction of stereotypic meanings and juxtaposition of counter-valorizations, whose effect was the coconstruction of critical-ironical alignments. We believe that these two "places" in contact in literacy practices - enabled by the mestizaje of school culture and popular culture - have triggered moments, however subtle they may be, of local dislodgement. Or as Butler (1994, p. 34) puts it, "we need to pursue the moments of degrounding, when we are standing in two different places at once; or [when] we don't know exactly where we are standing; or when we've produced an aesthetic practice [or a logic] that shakes the ground". But what kind of disturbance was achieved? What form of de-grounding, de-territorialization and meaning perturbation were attained?

Based on this group's experiences we can only talk about light oscillations and shimmering, not quakes. However, their observation has generated important theoretical insights concerning small-scale transgressions. They can only be detected if we turn our attention not to palpable and easily discernible transformative action but to dispersed and discontinuous "transformation streams" - inherently hybrid processes deriving from the attrition of contrasting discourses and meanings. Hibridity, therefore, as an educational procedure conceived not as mere mixing, but rather as a complex mosaic of rubbing texts and discourses, always in motion, has proven to be a socially significant enabling force - a borderland territory where structural boundaries and constraints can be rethought, agency dialogically crafted and innovation articulated.

The reinvention of social life has to do with inhabiting the borderland and engaging in what we have termed trans-experiences. The hybrid literacy environment we have studied has shown but one possibility, in the educational scenario, of dwelling on the border and responding to fluidity in an assured fashion. Certainly many other potentialities may be envisaged. We hope that the positive transformative flows apprehended in our investigation may come to contribute to projects seeking societal renewal and transfiguration in literacy contexts. 
Recebido em: maio de 2015

Aprovado em: outubro de 2015 brancaff@globo.com moitalopes@oi.com.br

\section{REFERENCES}

AGHA, A. (2005). Voice, footing and enregisterment. Journal of Linguistic Anthropology, vol. 15:1, pp. 38-59.

APPADURAI, A. (1996). Modernity at large: cultural dimensions of globalization. Minneapolis: University of Minnesota Press.

BAKHTIN, M. M. (1981). The dialogic imagination: four essays. Michael Holquist (Ed.). Austin: The University of Texas Press.

BRAH, A.; COOMBES, A. E. (Eds.) (2000). Hybridity and its discontents: politics, science and culture. London: Routledge.

BUCCI, E. (2004). Ainda sob o signo da Globo. In: Bucci, E.; Kehl, M. R. Videologias. São Paulo: Boitempo, pp. 220-240.

; KEHL, M. R. (2004). Videologias. São Paulo: Boitempo.

BUTLER, J. (2004). Undoing gender. New York: Routledge.

(1994). Gender as performance: an interview with Judith Butler. Interview by Peter Osborne and Lynne Segal. London, 1993. Radical Philosophy, 67: 32-39.

(1990). Gender trouble: feminism and the subversion of identity. New York: Routledge.

CANCLINI, N. (1987/2000). Culturas híbridas. Estratégias para entrar e sair da modernidade. Trans. Heloísa P. Cintrão. São Paulo: Editora da Universidade de São Paulo.

(n/d). La globalización? Productora de culturas híbridas? Mimeo.

COPE, B.; KALANTZIS, M. (2000a). Multiliteracies: literacy learning and the design of social futures. London: Routledge.

COPE, B.; KALANTZIS, M. (2000b). Designs for social futures. In Cope, B.; Kalantzis, M.

Multiliteracies: literacy learning and the design of social futures. London: Routledge, pp. 203- 234.

COUPLAND, N.; GARRETT, P.; WILLIAMS, A. (2005). Narrative demands, cultural performance and evaluation: teenage boys' stories for their age peers. In Thornborrow, J.; Coates, Jennifer (Eds.) The sociolinguistics of narrative. Amsterdam: John Benjamins, pp. 67-88.

EGAN-ROBERTSON, A.; BLOOME, D. (Eds.) (1998). Students as researchers of culture and language in their own communities. New Jersey: Hampton Press.

FABRÍCIO, B. F (2012). Trajectories of socialization in school transcontexts: discourse journeys on gender and sexuality, Working Papers in Urban Language \& Literacies 94, 2012, available at www.kcl.ac.uk/ldc. 
; MOITA-LOPES, L. P. (2010). A dinâmica dos (re)posicionamentos de sexualidade em práticas de letramento escolar: entre oscilações e desestabilizações sutis. In Moita Lopes, L. P.; Bastos, L. C. (Eds.) Para além da identidade: fluxos, movimento e trânsitos. Belo Horizonte: Ed. UFMG, pp. 283- 314.

GEE, J. P. (1994). Orality and literacy: from The Savage Mind to Ways with Words. In Maybin, J. (Ed.) Language and literacy in social practice. Clevedon: Multilingaul Matters, pp. 168-192.

GOFFMAN, E. (1974). Frame analysis. Cambridge, MA: Harvard University Press. . (1981). Footing. Forms of talk. Philadelphia: University of Pennsylvania Press.

GRUZINSKI, S. (1999). O pensamento mestiço. Trans. Rosa Freire d'Aguiar. São Paulo: Companhia das Letras.

JAGOSE, A. (1996). Queer theory. An introduction. New York: New York University Press.

KRESS, G. (2003). Literacy in the new media age. London: Routledge.

MARTÍN-BARBERO, J. (2001). Dos meios às mediações. Comunicação, cultura e hegemonia. Trans. Ronald Polit; Sérgio Alcides. Rio de Janeiro: Editora UFRJ.

MAYBIN, J.; MOSS, G. (1993). Talk about texts: reading as a social event. Journal of Research in Reading 16 (2), 138-137.

MIGNOLO, W. D. (2000) Local histories / Global designs. Coloniality, subaltern knowledges and border thinking. Princeton: Princeton University Press.

MOITA-LOPES, L. P. (2006/2011). Por uma linguística aplicada indisciplinar. São Paulo: Parábola.

(2010). Os novos letramentos digitais como lugares de construção de ativismo político sobre sexualidade e gênero. Trabalhos de Linguística Aplicada, 49 (2), 393-417.

(2005). A construção do gênero e do letramento na escola: como um tipo de conhecimento gera o outro. Investigações Linguísticas e Literárias, 17, 47-68.

PENNYCOOK, A. (2007). Global Englishes and transcultural flows. London: Routledge. (2010). Language as a local Practice. London: Routledge.

ROBERTSON, R. (1995). Glocalization: time-space and homogeneity-heterogeneity. In: M. Featherstone, M.; Lash, S. and Robertson, Roland. (Eds.) Global Modernities. London: Sage.

SARLO, B. (2000). Cenas da vida pós-moderna. Intelectuais, arte e videocultura na Argentina. Trans. Sérgio Alcides. Rio de Janeiro: Editora UFRJ.

SULLIVAN, N. (2003). A critical introduction to queer theory. New York: New York University Press.

TRAVANCAS, I. (2007). Juventude e televisão. Rio de Janeiro: Editora FGV. 
THOMAS, Ni. (2000). Technologies of conversion: cloth and Christianity in Polynesia. In BRAH, A.; COOMBES, Anne E. (Eds.) Hybridity and its discontents: politics, science and culture. London: Routledge, pp. 198-215.

VENN, C. (2000). Occidentalism. Modernity and Subjectivity. London: Sage.

\section{Appendix - Example of lessons in a hybrid syllabus}

\begin{tabular}{|c|c|c|c|c|c|}
\hline CLASS & STAGE & PROCEDURES & $\begin{array}{l}\text { SPATIAL } \\
\text { ARRANGEMENT }\end{array}$ & MATERIAL & PURPOSE \\
\hline 4 & $\begin{array}{l}\text { Analysis of media texts } \\
\text { defying static views of } \\
\text { gender }\end{array}$ & $\begin{array}{l}\text {-Students read different } \\
\text { texts; } \\
\text {-they work in pairs, } \\
\text { exchanging ideas } \\
\text { concerning their texts } \\
\text { - class discussion } \\
\text { - homework: students } \\
\text { should look for media } \\
\text { imagetic texts } \\
\text { containing gender } \\
\text { stereotypes and or } \\
\text { ideas that may disturb } \\
\text { them; they should also } \\
\text { write a small paragraph } \\
\text { justifying their choices. }\end{array}$ & $\begin{array}{l}\text { Desks organized in } \\
\text { two big rows facing } \\
\text { each other; teacher } \\
\text { moves in between } \\
\text { them }\end{array}$ & $\begin{array}{l}\text { Three newspaper } \\
\text { articles: } \\
\text { "Women handle } \\
\text { prejudice in the } \\
\text { world of samba"- } \\
\text { on women playing } \\
\text { at the rhythm } \\
\text { sections of a samba } \\
\text { school band } \\
\text { "Difference" - } \\
\text { interview with a } \\
\text { woman pilot and } \\
\text { with a man who } \\
\text { deals in cosmetics" } \\
\text { "When prejudice } \\
\text { gets going"- article } \\
\text { about a woman } \\
\text { shooter who keeps } \\
\text { guard over a } \\
\text { company. }\end{array}$ & $\begin{array}{l}\text { - Reflecting about } \\
\text { alternative gender } \\
\text { meanings }\end{array}$ \\
\hline
\end{tabular}

\begin{tabular}{|c|l|l|l|l|l|}
\hline CLASS & STAGE & PROCEDURES & $\begin{array}{l}\text { SPATIAL } \\
\text { ARRANGEMENT }\end{array}$ & MATERIAL & PURPOSE \\
\hline 5 & Task presentation & $\begin{array}{l}\text {-Students present their } \\
\text { work; } \\
\text {-in groups of three, } \\
\text { they stand in front of } \\
\text { the group and they take } \\
\text { turns sharing ideas } \\
\text { with classmates }\end{array}$ & $\begin{array}{l}\text { Traditional spatial } \\
\text { arrangement; teacher } \\
\text { mingles with students, } \\
\text { occupying one of the } \\
\text { desks }\end{array}$ & $\begin{array}{l}\text { Tasks prepared by } \\
\text { students }\end{array}$ & $\begin{array}{l}- \text { Reflecting about } \\
\text { stereotypical and } \\
\text { alternative } \\
\text { approaches to } \\
\text { gender }\end{array}$ \\
& & & & \\
& & & & \\
\hline
\end{tabular}

\begin{tabular}{|c|c|c|c|c|c|}
\hline CLASS & STAGE & PROCEDURES & $\begin{array}{l}\text { SPATIAL } \\
\text { ARRANGEMENT }\end{array}$ & MATERIAL & PURPOSE \\
\hline 6 and 7 & $\begin{array}{l}\text { Interfacing students' co- } \\
\text { constructed discourse } \\
\text { with official curriculum }\end{array}$ & $\begin{array}{l}\text { - Individual reading of } \\
\text { text in the history } \\
\text { book; } \\
\text { - students work in pairs } \\
\text { making a list of the } \\
\text { main ideas in the text } \\
\text { - different pairs share } \\
\text { their ideas with the } \\
\text { group as teachers write } \\
\text { contributions on the } \\
\text { chalkboard } \\
\text { - teacher wraps-up } \\
\text { discussion }\end{array}$ & $\begin{array}{l}\text { - Traditional spatial } \\
\text { arrangement } \\
\text { - students work in } \\
\text { pairs by moving two } \\
\text { desks together, so that } \\
\text { they can face each } \\
\text { other }\end{array}$ & $\begin{array}{l}\text { - History Book } \\
\text { - "Women from } \\
\text { Athens", song by } \\
\text { Chico Buarque, a } \\
\text { contemporary } \\
\text { Brazilian musician } \\
\text { and lyricist }\end{array}$ & $\begin{array}{l}\text { - Reflecting about } \\
\text { women's role in } \\
\text { Greek society }\end{array}$ \\
\hline
\end{tabular}

